19 National Diabetes Data Group. Classification and diagnosis of diabetes mellitus and other categories of glucose intolerance. Diabetes 1979;28 $1039-57$

20 Joint National Committee on Detection, Evaluation, and Treatment of High Blood Pressure. The 1984 report of the joint national committee on detection, evaluation, and treatment of high blood pressure. Arch Intern Med 1984;144:1045-7.

21 Jerums G, Cooper M, Seeman E, Murray RML, McNeil JJ. Spectrum of proteinuria in type I and type II diabetes. Diabetes Care 1987;10:419-27.

22 Greenwood PC, Hunter WM, Glover JS. The preparation of "'I-labelled human growth hormone of high specific radioactivity. Biochem $\mathcal{F}$ 1963;89: 114-23.

23 Mendelsohn FAO, Hutchinson J, Johnston CI. A review of plasma renin measurements and their clinical significance. Aust NZ F Med 1971;1:86-93.

24 Cushman DW, Cheung HS. Spectrophotometric assay and properties of the angiotensin converting enzyme of rabbit lung. Biochem Pharmacol 1971;20 $1637-48$.

25 Dubovsky EV, Russell CD. Quantitation of renal function with glomerular and tubular agents. Semin Nucl Med 1982;12:308-29.

26 Bach LA, Sharpe K. Sample size for clinical and biological research. Aust NZf Med 1989;19:64-8.

27 Gardner MJ, Altman DG. Statistics with confidence. London: BMF, 1989.

28 Matthews JNS, Altman DG, Campbell MJ, Royston P. Analysis of serial measurements in medical research. BMF 1990;300:230-5.

29 Biörck S, Mulec H, Johnsen SA, Nyberg G, Aurell M. Contrasting effects of enalapril and metoprolol on proteinuria in diabetic nephropathy. $B M \mathfrak{f}$ 1990;300:904-7.

30 Wiseman MJ, Viberti GC, Keen $\mathrm{H}$. Threshold effect of plasma glucose in the glomerular hyperfiltration of diabetes. Nephron 1984;38:257-60.

31 Christensen CK, Mogensen CE. The course of incipient diabetic nephropathy: studies of albumin excretion and blood pressure. Diabetic Med 1985;2: 97-102.

32 Feldt-Rasmussen B, Mathiesen E, Deckert T. Effect of two years of stric metabolic control in insulin-dependent diabetes. Lancet 1986;i:1300-4.

\section{Oxygen desaturation in apparent and relative polycythaemia}

\author{
M Messinezy, S Aubry, G O’Connell, \\ D F Treacher, T C Pearson
}

Division of Haematology, United Medical and Dental Schools of Guy's and St Thomas's Hospitals, St Thomas's Campus,

London SE1 7EH

M Messinezy, FRCPATH, clinical assistant

T C Pearson, FRCPATH, reader

Sleep Laboratory, United Medical and Dental Schools of Guy's and St Thomas's Hospitals, St Thomas's Campus, London SE1 7EH

S Aubry, HNC, sleep laboratory technician D F Treacher, MRCP, consultant physician

Lung Function Laboratory, Department of Medicine, St Thomas's Hospital, London SE1 7EH

G O'Connell, BTECH, senior physiological measurement technician

Correspondence to:

Dr Messinezy.

BMf 1991;302:216-7 mean normal value) and nine apparent polycythaemia (normal plasma volume). The following observations were recorded: daytime arterial oxygen saturation and carboxyhaemoglobin measured in a radial artery blood sample taken when the patient was sitting (ABL2 Radiometer, Copenhagen), oxygen saturation measured by pulse oximetry when stabilised in sitting and supine

Data for the four patients with arterial oxygen desaturation
33 Cooper ME, Frauman A, O'Brien RC, Seeman E, Murray RML, Jerums G. Progression of proteinuria in type I and type II diabetics. Diabetic Med 1988;5:361-8.

34 Cooper ME, Allen TJ, Macmillan P, et al. Effects of genetic hypertension on diabetic nephropathy in the rat-functional and structural characteristics. 7 Hypertens 1988;6:1009-16.

35 Cooper ME, Allen TJ, O'Brien RC, et al. Nephropathy in a model combining genetic hypertension with experimental diabetes: enalapril versus hydralazine and metoprolol therapy. Diabetes 1990;39:1575-9.

36 Edwards RM. Segmental effects of norepinephrine and angiotensin II on isolated renal microvessels. Am F Physiol 1983;244:F526-34.

37 Toshiaki S, Yasuo N, Shinya N, Yukio Y. Effect of calcium antagonist on hypertension and diabetes in new hypertensive diabetic models. $\mathcal{f}$ Cardiovasc Pharmacol 1987;10:S192-4.

38 Parving $\mathrm{HH}$, Hommel E, Smidt UM. Protection of kidney function an decrease in albuminuria by captopril in insulin dependent diabetics with nephropathy. $B M \mathcal{F}$ 1988;297:1086-91.

39 Pinto JR, Walker JD, Turner C, Beesley M, Viberti GC. Renal response to lowering of arterial pressure by angiotensin converting enzyme inhibitor or diuretic therapy in insulin-dependent diabetic patients with nephropathy. Kidney Int 1990;37:516.

40 Bakris GL. Effects of diltiazem or lisinopril on massive proteinuria associated with diabetes mellitus. Ann Intern Med 1990;112:707-8.

41 Marre M, Leblanc H, Suarez L, Guyenne T, Ménard J, Passa P. Converting enzyme inhibition and kidney function in normotensive diabetic patients with persistent microalbuminuria. BMF 1987;294:1448-52.

42 Brichard S, Ketelslegers JM, Lambert AE. Renal function, glycemic contro and perindopril in diabetic patients. Clin Exp Hypertens [A] 1989;11: $545-54$

43 Abu-Romeh SH, Nawaz MK, Ali JH, Al-Suhali AR, Abu-Jayyab AK. Shortterm effects of angiotensin converting enzyme inhibitor enalapril in incipient diabetic nephropathy. Clin Nephrol 1989;31:18-21.

(Accepted I November 1990)

positions (Ohmeda BIOX 3700) and routine lung function measured by spirometry, lung volume, and carbon monoxide transfer factor. A sleep study with readings of oxygen saturation and heart rate by pulse oximetry, nose-mouth air flow, and observation by a sleep laboratory technician (SA) was performed in all patients for over five hours.

Four patients (two with relative and two with apparent polycythaemia) had appreciable oxygen desaturation during sleep (table) and these were the only patients with reduced oxygen saturation values of less than $92 \%$ by daytime pulse oximetry (all four when supine and only one when sitting). ${ }^{4}$ Only one of these four patients and none of the remaining 12 had low daytime oxygen saturation measured in an arterial blood sample. The fall in oxygen saturation during sleep in these four patients related to hypoventilation as none had appreciable apnoea scores. Two of these four patients and three of the remaining 12 showed appreciable impairment of respiratory function - that is, forced expiratory volume in 1 second less than $70 \%$ of the predicted value or carbon monoxide transfer value less than $75 \%$ of the predicted value, or both. One of the four patients with reduced oxygen saturation values and nine of the remaining 12 were classified as cigarette smokers on the basis of history and carboxyhaemoglobin concentrations.

None of a control group of 16 age and sex matched haematology outpatients without polycythaemia had oxygen saturation values less than $92 \%$ when tested by supine oximetry.

\title{
Comment
}

Four of 16 consecutive patients with polycythaemia but normal red cell mass had evidence of appreciable nocturnal oxygen desaturation due to hypoventilation.

\begin{tabular}{|c|c|c|c|c|c|c|c|c|c|c|}
\hline \multirow{2}{*}{$\begin{array}{c}\text { Case } \\
\text { No }\end{array}$} & \multirow{2}{*}{$\begin{array}{l}\text { Daytime } \\
\text { arterial } \\
\text { oxygen } \\
\text { saturation } \\
\quad(\%)\end{array}$} & \multicolumn{2}{|c|}{$\begin{array}{l}\text { Oxygen saturation } \\
\text { measured by pulse } \\
\text { oximetry }(\%)\end{array}$} & \multirow{2}{*}{$\begin{array}{l}\text { Packed } \\
\text { cell } \\
\text { volume }\end{array}$} & \multirow{2}{*}{$\begin{array}{c}\text { Red cell } \\
\text { mass } \\
(\% \text { predicted })\end{array}$} & \multirow{2}{*}{$\begin{array}{c}\text { Plasma } \\
\text { volume } \\
\text { (\% predicted) }\end{array}$} & \multirow{2}{*}{$\underset{(\%)}{\text { Carboxyhaemoglobin }}$} & \multirow{2}{*}{$\begin{array}{l}\% \text { Total test time } \\
\text { at saturation } \\
<90 \% \text { from } \\
\text { sleep study }\end{array}$} & \multirow{2}{*}{$\begin{array}{c}\text { Forced } \\
\text { expiratory } \\
\text { volume in } 1 \mathrm{~s} \\
\text { (\% predicted) }\end{array}$} & \multirow{2}{*}{$\begin{array}{c}\text { Carbon } \\
\text { monoxide } \\
\text { transfer factor } \\
(\% \text { predicted })\end{array}$} \\
\hline & & Sitting & Supine & & & & & & & \\
\hline 1 & 97 & 91 & 88 & 0.53 & 114 & 99 & 1.0 & 79 & 99 & 96 \\
\hline 2 & 95 & 95 & 90 & 0.52 & 110 & 98 & 0.9 & 5 & 95 & $>90$ \\
\hline 3 & 91. & 93 & 86 & 0.54 & 106 & 80 & 3.9 & 54 & 29 & 42 \\
\hline 4 & 94 & 92 & 89 & 0.52 & 93 & 84 & $1 \cdot 2$ & 8 & 50 & $>90$ \\
\hline
\end{tabular}


In all four this was predicted by daytime oximetry in a supine position, although only one had a low arterial oxygen saturation when sitting. This probably relates to the difference in posture and the less stressful nature of oximetry. Coincidental pulmonary disease probably related to smoking was present in only one of the patients with arterial oxygen desaturation.

This study shows that it is important to investigate patients with apparent and relative polycythaemia for oxygen desaturation not only by measuring daytime arterial blood gases but also by supine oximetry. Studies of the mechanisms of plasma volume control, which are altered in hypoxaemia, ${ }^{5}$ may help to determine whether the association of hypoxaemia and raised packed cell volume without an increased red cell mass is a causal one.

1 Moore-Gillon J, Treacher DF, Gaminara EJ, Pearson TC, Cameron IC Intermittent hypoxia in patients with unexplained polycythaemia. $B M Y$ 1986;293:588-90.

2 Messinezy $M$, Pearson TC. A retrospective study of apparent and relative polycythaemia: associated factors and early outcome. Clin Lab Haemato 1990;12:121-9.

3 Pearson TC, Guthrie DL. The interpretation of measured red cell mass and plasma volume in patients with elevated PCV values. Clin Lab Haematol 1984;6:207-17.

4 Berlin NI. Diagnosis and classification of polycythaemia. Semin Hematol 1975;12:339-51.

5 Eckstein JW, Horsley AW. Effects of hypoxia on peripheral venous tone in man. Journal of Laboratory and Clinical Investigation 1960;56:847-53.

(Accepted 2 October 1990)

\section{Prescribing of psychotropic drugs to children and adolescents}

\author{
Sue Adams
}

To date there have been no surveys of the prescribing of psychotropic drugs to children and adolescents, but this use of psychotropic drugs had been accepted since the first observations by Charles Bradley in 1937 that amphetamine sulphate (Benzedrine) modified the behaviour of children with severe behavioural disturbance. ${ }^{1}$ Since those early reports there have been more and more reports favouring the use of stimulants, ${ }^{2}$ tricyclic antidepressants (including their use for nocturnal enuresis), ${ }^{3}$ antipsychotic drugs in adolescent psychoses ${ }^{4}$ and lithium in adolescent manic depressive disorder. ${ }^{5}$ Minor tranquillisers and sedative antihistamines seem to be widely used to treat sleep disturbance, but there has been virtually no systematic investigation of this use. The aim of my study was to find how often these drugs are prescribed and the general pattern of drug type, indication, and prescriber.

\section{Patients, methods, and results}

The survey was based on a simple postal questionnaire (designed to maximise the response rate). Drugs were divided into seven different classes according to the drug group and indication for treatment (table). To

Numbers of prescriptions for psychotropic drugs given by 83 general practitioners and 22 consultant child psychiatrists in 3 month period to children aged $\leqslant 7,8-13$, and 14-17 years

\begin{tabular}{|c|c|c|c|c|c|c|}
\hline \multirow[b]{2}{*}{ Drug } & \multicolumn{3}{|c|}{$\begin{array}{l}\text { Prescribed by general } \\
\text { practitioners }\end{array}$} & \multicolumn{3}{|c|}{$\begin{array}{c}\text { Prescribed by } \\
\text { consultants }\end{array}$} \\
\hline & $\leqslant 7$ & 8-13 & $14-17$ & $\leqslant 7$ & $8-13$ & $14-17$ \\
\hline \multicolumn{7}{|l|}{ Tranquillisers: } \\
\hline Major & 0 & 0 & 2 & 1 & 3 & 18 \\
\hline Minor & 1 & 0 & 4 & 0 & 2 & 3 \\
\hline Hypnotics & 61 & 3 & 6 & 13 & 0 & 0 \\
\hline \multicolumn{7}{|l|}{ Antidepressants: } \\
\hline For depression & 3 & 2 & 9 & 0 & 4 & 9 \\
\hline For enuresis & 28 & 27 & 4 & 4 & 6 & 1 \\
\hline Lithium & 0 & 0 & 1 & 0 & 1 & 4 \\
\hline Stimulants & 0 & 0 & 0 & 1 & 3 & 0 \\
\hline
\end{tabular}

maintain the simple design of the questionnaire three age ranges were used, which were chosen to reflect the logical differences in prescribing with age. The age ranges were 7 years and under, 8-13, and 14-17 years, reflecting the infant and developmental period, childhood, and adolescence, respectively.

One hundred general practitioners randomly indentified from the current Wessex Family Health Services Authority list and all 28 consultant child psychiatrists in practice in Wessex were surveyed. The questionnaire inquired retrospectively about prescriptions given over the previous three months. It was ${ }_{\sigma}^{\omega}$ emphasised that only those prescriptions given on a $\bar{O}$ doctor's own initiative, rather than in response to 3 . another doctor's recommendation, should be counted. $\dot{\sigma}$ Those doctors who failed to reply were sent a second $N$ questionnaire.

Correctly completed replies were received from $83 \bigcirc$ general practitioners and 22 consultants. Sixty iِ one general practitioners had given a total of $151 \%$ prescriptions and 16 consultants 73 prescriptions. The 음 table shows the numbers of prescriptions given in each N category.

\section{Comment}

This study provides some initial data about the $\vec{\theta}$ pattern of psychotropic drug prescribing to children and adolescents in both general practice and child $\sigma$ psychiatric practice. The response rate by both general practitioners and consultants was good, probably reflecting the simplicity of the questionnaire and the efforts made to encourage a reply. That in a three $\frac{\circ}{\mathbb{D}}$ month period as many as $73 \%$ of general practitioners and $68 \%$ of consultant child psychiatrists prescribed a psychotropic drug to a child of 17 years or under was surprising and indicates a need for further studies. Perhaps there should also be some concern that several prescriptions of antidepressants for depression were made by general practitioners on their own initiative without the recommendation of a consultant. Also surprising is the prescribing of antidepressants for enuresis to so many children in the youngest age group, $\stackrel{8}{0}$ in whom such symptoms might be regarded as lying within the spectrum of normality. In addition, it is probably questionable whether young children or $N$ babies should be prescribed hypnotics for sleep $\rightarrow$ problems. There are dangers in prescribing psycho-o tropic drugs to children; in addition to the possibility of dangerous and unpleasant side effects there is 0 the risk of accidental poisoning and deliberate self $\omega$ harm by overdosing, which is a common adolescent problem.

I thank Dr Denis O'Leary and Dr Alastair Mackie for $\stackrel{\mathscr{C}}{?}$ supervision of this project.

1 Bradley C. The behaviour of children receiving Benzedrine. Am $\mathcal{f}$ Psychiatry 1937;94:577-85.

Rapoport JL. The use of drugs: trends in research. In: Rutter M, ed. Developmental neuropsychiatry. New York: Guildford Press, 1983:385-403, Shaffer D, Costello AJ, Hill LD. Control of enuresis with imipramine. Arch Dis Child 1968;43:665-71

4 Steinberg D. Psychotic and other severe disorders in adolescence. In: Rutter $M O$ Hersov L, eds. Child and adolescent psychiatry: modern approaches. Oxford:

5 Varanka TM, Weller RA, Weller EB, Fristad MA. Lithium treatment of manic episodes with psychotic features in prepubertal children. Am $\mathcal{F}$ Psychiatry 1988:145:1557-9.

(Accepted 12 October 1990) 